\title{
Antimicrobial activity of oregan and clove essential oils against some foodborne pathogens
}

\section{Atividade antimicrobiona dos óleos essenciais de orégano e cravo frente a patógenos alimentares}

\author{
Flávia Debiagi ${ }^{1}$, Renata K. T. Kobayashi ${ }^{2}$, Gerson Nakazato ${ }^{3}$, \\ Luciano A. Panagio ${ }^{4}$, Suzana Mali ${ }^{5}$
}

\begin{abstract}
The tendency to replace synthetic antimicrobials for natural ones in food industry and an increase in bacterial resistance to antibiotics resulted in a necessity to find new alternatives, and essential oils are emerging as promising substitutes for synthetic chemicals in food preservation. The objective of this work was to test the antimicrobial activity of oregano (OEO) and clove (CEO) essential oils over a range of bacteria, molds and yeast of importance as pathogens or food spoilage. The antimicrobial activity of oregano and clove essential oils were analyzed by disk diffusion method and broth microdilution test (MIC) of OEO and CEO were determined for each tested microorganism. $\mathrm{OEO}$ and CEO were evaluated in natura (IN) and after thermal processing (TP) at $120{ }^{\circ} \mathrm{C}$ for 5 min. Both OEO and CEO presented the same inhibition zones for IN and TP samples, for all tested microorganisms, indicating that these oils can be thermally processed maintaining their antimicrobial activity. For OEO and CEO, the more sensitive microorganisms were the fungi (Aspergillus niger, Penicillium citrinum and Candida albicans), followed by Staphylococcus aureus, Bacillus cereus and Methicillin - resistant Staphylococcus aureus (MRSA); the lowest antimicrobial activities were observed against Streptococcus mutans and Enterococcus faecalis. In general, OEO resulted in higher inhibition zones and lower MIC values for all tested microorganisms, suggesting that it was more effective as an antimicrobial agent than CEO.
\end{abstract}

Keywords: Disk diffusion method. Minimal inhibitory concentrations. Natural antimicrobials.

$1 \mathrm{PhD}$ in Biotechnology, State University of Londrina, Londrina, Paraná, Brazil. Professor in the Department of Biochemistry and Biotechnology, State University of Londrina, Londrina, Paraná, Brazil. E-mail: flaviadebiagifassina@gmail.com

$2 \mathrm{PhD}$ in Microbiology, State University of Londrina, Londrina, Paraná, Brazil. Professor in the Department of Microbiology, State University of Londrina, Londrina, Paraná, Brazil.

$3 \mathrm{PhD}$ in Genetics and Molecular Biology, State University of Campinas, Campinas, São Paulo, Brazil. Professor in the Department of Microbiology, State University of Londrina, Londrina, Paraná, Brazil.

$4 \mathrm{PhD}$ in Basic and Applied Immunology, University of São Paulo, Ribeirão Preto, São Paulo, Brazil. Professor in the Department of Microbiology, State University of Londrina, Londrina, Paraná, Brazil.

$5 \mathrm{PhD}$ in Food Sciences, University of Londrina, Londrina, Paraná, Brazil. Professor in the Department of Biochemistry and Biotechnology, State University of Londrina, Londrina, Paraná, Brazil. 


\section{Resumo}

A preferência mundial para alimentos mais saudáveis e livres de aditivos químicos pelos consumidores, associada ao aumento da resistência bacteriana, resultaram na necessidade de medidas alternativas no setor de alimentos. Os óleos correspondem a antimicrobianos naturais e constituem uma classe emergente como substitutos dos produtos químicos sintéticos na conservação de alimentos. $\mathrm{O}$ objetivo deste trabalho foi avaliar a atividade antimicrobiana de óleos essenciais de orégano (OEO) e cravo (CEO ) frente a bactérias, fungos e leveduras de importância no setor de alimentos. OEO e CEO foram avaliados in natura (IN) e após processamento térmico (TP) a $120^{\circ} \mathrm{C}$ por 5 minutos. Para avaliar a atividade antimicrobiana frente a cada microrganismo empregou-se o método de discodifusão e o teste de microdiluição em caldo (MIC). Tanto o OEO quanto o CEO apresentaram zonas de inibição semelhantes para amostras IN e TP, indicando que a atividade antimicrobiana desses óleos são resistentes a altas temperaturas. Os microrganismos mais sensíveis para ambos os óleos essenciais foram os fungos (Aspergillus niger, Penicillium citrinum e Candida albicans), seguidos por Staphylococcus aureus, Bacillus cereus e Staphylococcus aureus resistente à meticilina (MRSA). Já as cepas Streptococcus mutans e Enterococcus faecalis apresentaram uma maior resistência frente à atividade antimicrobiana dos óleos essenciais. Em geral, os maiores halos de inibição e menores valores de MIC foram obtidos quando empregado o OEO, sugerindo uma maior atividade microbiana do mesmo quando comparado ao CEO.

Palavras-chave: Método de disco-difusão. Concentração inibitória mínima. Antimicrobianos naturais.

\section{Introduction}

Foodborne illness (FDB) are diseases caused by eating contaminated food for pathogenic microorganisms, such as bacteria, fungi, viruses, parasites or with poisonous chemicals or biotoxins. The occurrence of FBD can be associated with manipulation, inadequate preservation and or environmental contamination, which are the main way of transmission of pathogenic microorganisms to foods. ${ }^{(1)}$

FDB have mild and self-limiting symptoms, but there is high risk group, which is constituted by infants, young children, the elderly and the immunocompromised persons. In this group, FDB is an important cause of morbidity and mortality, mainly in the developing countries, for example, in Brazil, between 2000 and 2017 there were reported 12.660 outbreaks and 186 deaths. ${ }^{(2)}$

Routinely, the chemical sanitizers, such as chlorine compounds, peroxide and peroxyacid mixtures, carboxylic acids, quaternary ammonium compounds, acid anionic, and iodine compounds are employed to disinfect food contact surfaces in food industry. As a consequence, the use of chemical disinfectants must to produce unhealthy by-products or antimicrobial resistance in bacteria. ${ }^{(3)}$ On the other hand, antimicrobials derived from plants extracts are emerging as promising substitutes for conventional antimicrobials employed in food industry as an eco-friendly alternative.

Essential oils (EOs) are natural volatile liquids compounds that can be also called volatile or ethereal oils, which can be synthesized by all plant organs during the secondary metabolism. ${ }^{(4)}$ Many essential oils are found on the U.S. Food and Drug Administration's (FDA) Generally Recognized as Safe (GRAS) list, so they are extensively used as flavoring agents in baked goods, sweets, ice cream, beverages and chewing gum. Approximately, 3000 EOs are known and about 300 types are commercially available, including oregano (OEO) and clove essential (CEO) oils, which are described as most effective ones. ${ }^{(4-5)}$ The major components of EOs are terpenoid and phenolic compounds, such as carvacrol, eugenol and thymol, which are responsible for their antimicrobial activity. The antimicrobial mechanism of action can be associated with degradation of the cell wall, disturbance of the cytoplasmic membrane, leakage 
of cell contents, coagulation of cytoplasm and disrupting the proton motive force. (4,6-7) $^{-19}$

The objective of this work was to determine the antimicrobial activity of oregano and clove essential oils over a range of bacteria, molds and yeast of importance as pathogens or food spoilage.

\section{Material and Methods}

\section{Material}

Oregano (Origanum vulgare) and clove (Eugenia caryophyllata) essential oils were purchased from Ferquima (Ferquima Indústria e Comércio Ltda, Vargem Grande Paulista, São Paulo). The following food-borne microbial strains were selected for use in the assays because of their relevance in the food industry: the Gram-positive bacteria Staphylococcus aureus (ATCC 6538), Methicillin - resistant Staphylococcus aureus (MRSA) N315, Bacillus cereus, Streptococcus mutans (ATCC 25175) and Enterococcus faecalis (ATCC 6569); the Gram-negative bacteria Escherichia coli (ATCC 8739) and Salmonella enterica subsp. enterica serovar Typhimurium ( $S$. Typhimurium) (ATCC 14028); the yeast Candida albicans (ATCC 90028); and the molds Aspergillus niger and Penicillium citrinum were obtained from the culture collection of the Laboratory of Basic and Applied Bacteriology and Laboratory of Medical Mycology, Department of Microbiology of the State University of Londrina.

\section{Antimicrobial activity of the essential oils}

\section{Disk diffusion method}

The disc inhibition zone method was employed to determine qualitatively the antimicrobial activity of the OEO and CEO according to Gómez-Estaca et al. ${ }^{(8)}$ with modifications. Due to the presence of volatile compounds among the active components of EOs, they were evaluated in natura (IN) and after thermal processing (TP) at $120{ }^{\circ} \mathrm{C}$ for $5 \mathrm{~min}$. Different EOs volumes (1, 2, 5 and $10 \mu \mathrm{L})$ were added onto aseptic discs. Then, the discs were placed on plates containing Mueller-Hinton (MHA) agar (Himedia, India), which were previously spread with 0.1 $\mathrm{mL}$ of inoculums containing $10^{8} \mathrm{CFU} / \mathrm{mL}$ of bacterial cultures, previously standardized using the McFarland scale. The plates were incubated at $37 \pm 0.5{ }^{\circ} \mathrm{C}$ for $18-24 \mathrm{~h}$. Sabouraud Agar (Neogen, USA) was employed to investigate the antimicrobial activity against $C$. albicans culture, and the plates were incubated at $27 \pm 0.5^{\circ} \mathrm{C}$ for 18 - $24 \mathrm{~h}$. For the molds (A. niger and P. citrinum), a spore suspension stock of each one was diluted in sterile to obtain $10^{6}$ spores $\mathrm{ml}^{-1}$. The spores were enumerated by direct counting using a Neubauer chamber and placed on plates with Sabouraud Agar (Neogen, USA) that were incubated at $27 \pm$ $0.5{ }^{\circ} \mathrm{C}$ for 5 days.

After incubation, microbial growth was observed on the plates, and the inhibition zone diameters (colony-free perimeter) were measured with a caliper. Data were expressed as inhibition zones $(\mathrm{mm})$. Each experiment was performed in triplicate.

\section{Minimal inhibitory concentrations (MICs)}

The minimal inhibitory concentrations (MICs) were employed to quantitatively determined the antimicrobial activity of IN and TP EOs. The MIC of CEO was determined by microdilution assays in 96-well plates ${ }^{(9)}$. Bacterial $\left(1.5 \times 10^{8}\right.$ $\mathrm{CFU} / \mathrm{mL})$ suspensions were diluted in MuellerHinton broth (Difco, USA), and molds ( $10^{6}$ spores/ $\mathrm{mL})$ and yeast $\left(1.5 \times 10^{8} \mathrm{CFU} / \mathrm{mL}\right)$ suspensions in RPMI medium (Sigma, USA). Then, they were plated in 96-well plates at a density of $5.0 \times 10^{5}$ $\mathrm{CFU} / \mathrm{mL}$. Finally, different volumes of OEO were added to each well to determine the MIC values. The plates were incubated at $36.5 \pm 0.5^{\circ} \mathrm{C}$ for 18 - 24h (bacteria and yeast), and at $27 \pm 0.5^{\circ} \mathrm{C}$ for 5 days (molds). After incubation, MIC was defined as the lowest concentration of antimicrobial agent 
that inhibited visible growth.

The MIC IN and TP OEO was evaluated by microdilution assay ${ }^{(10)}$ in microtubes. Bacterial (1.5 $\times 10^{8} \mathrm{CFU} / \mathrm{ml}$ ) suspensions were diluted in MuellerHinton broth (Difco, USA), and molds $\left(10^{6}\right.$ spores/ $\mathrm{mL})$ and yeast $\left(1.5 \times 10^{8} \mathrm{CFU} / \mathrm{mL}\right)$ suspensions in RPMI medium (Sigma, USA). Finally, different volumes of OEO were added to each microtube to determine the MIC values. The microtubes were incubated at $36.5 \pm 0.5^{\circ} \mathrm{C}$ for $18-24 \mathrm{~h}$ (bacteria and yeast), and at $27 \pm 0.5^{\circ} \mathrm{C}$ for 5 days (molds).

\section{Results and Discussion}

The antimicrobial activities of OEO and CEO were evaluated using the disk diffusion method, and the results were presented in Tables 1 and Figure 1 for OEO, and Table 2 and Figure 2 for CEO. Both OEO (Table 1) and CEO (Table 2) presented the same inhibition zones for IN and TP oils, for all tested microorganisms, indicating that these oils can be thermally processed $\left(120^{\circ} \mathrm{C} / 5\right.$ min) maintaining their antimicrobial activity.

Table 1 - Mean inhibition zone diameters $(\mathrm{mm})$ for the different volumes $(1,2,5$ and $10 \mu \mathrm{L})$ of oregano essential oil in natura (IN) and thermally processed (TP) against the tested microorganisms.

\begin{tabular}{|c|c|c|c|c|c|c|c|c|}
\hline \multirow{4}{*}{ Microorganisms } & \multicolumn{4}{|c|}{ IN } & \multicolumn{4}{|c|}{$\mathrm{TP}$} \\
\hline & \multicolumn{8}{|c|}{ Volume $(\mu \mathrm{L})$} \\
\hline & 1 & 2 & 5 & 10 & 1 & 2 & 5 & 10 \\
\hline & \multicolumn{8}{|c|}{ Inhibition zone (mm) } \\
\hline S. aureus & 20 & 30 & 50 & 60 & 20 & 30 & 50 & 60 \\
\hline MRSA & 30 & 32 & 34 & 35 & 30 & 32 & 34 & 35 \\
\hline B. cereus & 35 & 38 & 39 & 39 & 35 & 38 & 39 & 39 \\
\hline S. mutans & 10 & 18 & 25 & 27 & 10 & 18 & 25 & 27 \\
\hline E. faecalis & 8 & 10 & 12 & 13 & 8 & 10 & 12 & 13 \\
\hline E. coli & 10 & 19 & 23 & 30 & 10 & 19 & 23 & 30 \\
\hline$S$. Typhimurium & 17 & 20 & 22 & 30 & 17 & 20 & 22 & 30 \\
\hline C. albicans & 47 & 65 & $\mathrm{TI}$ & TI & 47 & 65 & TI & $\mathrm{TI}$ \\
\hline A. niger & 45 & 70 & TI & TI & 45 & 70 & $\mathrm{TI}$ & $\mathrm{TI}$ \\
\hline P. citrinum & TI & $\mathrm{TI}$ & TI & TI & TI & TI & $\mathrm{TI}$ & $\mathrm{TI}$ \\
\hline
\end{tabular}

Font: Authors

$\mathrm{TI}=$ total inhibition. 
For OEO (Table 1, Figure 1), the more sensitive microorganisms were the fungi ( $A$. niger, $P$. citrinum and $C$. albicans), followed by $S$. aureus, B. cereus and MRSA. The lowest antimicrobial activity was observed against $E$. faecalis and $S$. mutans. For CEO (Table 2, Figure 2 ), the more sensitive microorganisms were also the fungi as observed for OEO, followed by $S$. aureus and MRSA. The lowest antimicrobial activity was also observed against E. faecalis and $S$. mutans. According to Yoshida and Kuramitsu $^{(11)}$, these bacteria are able to form a biofilm that can reduce the antimicrobial effect of the EOs.

Figure 1 - Disk diffusion images using $5 \mu \mathrm{L}$ of in natura - OEO (1) and thermal processed OEO (2): (A) S. aureus; (B) B. cereus; (C) S. mutans; (D) E. faecalis; (E) E. coli; (F) S. Typhimurium; (G) C. albicans; (H) A. niger; (I) P. citrinum; (J) MRSA.
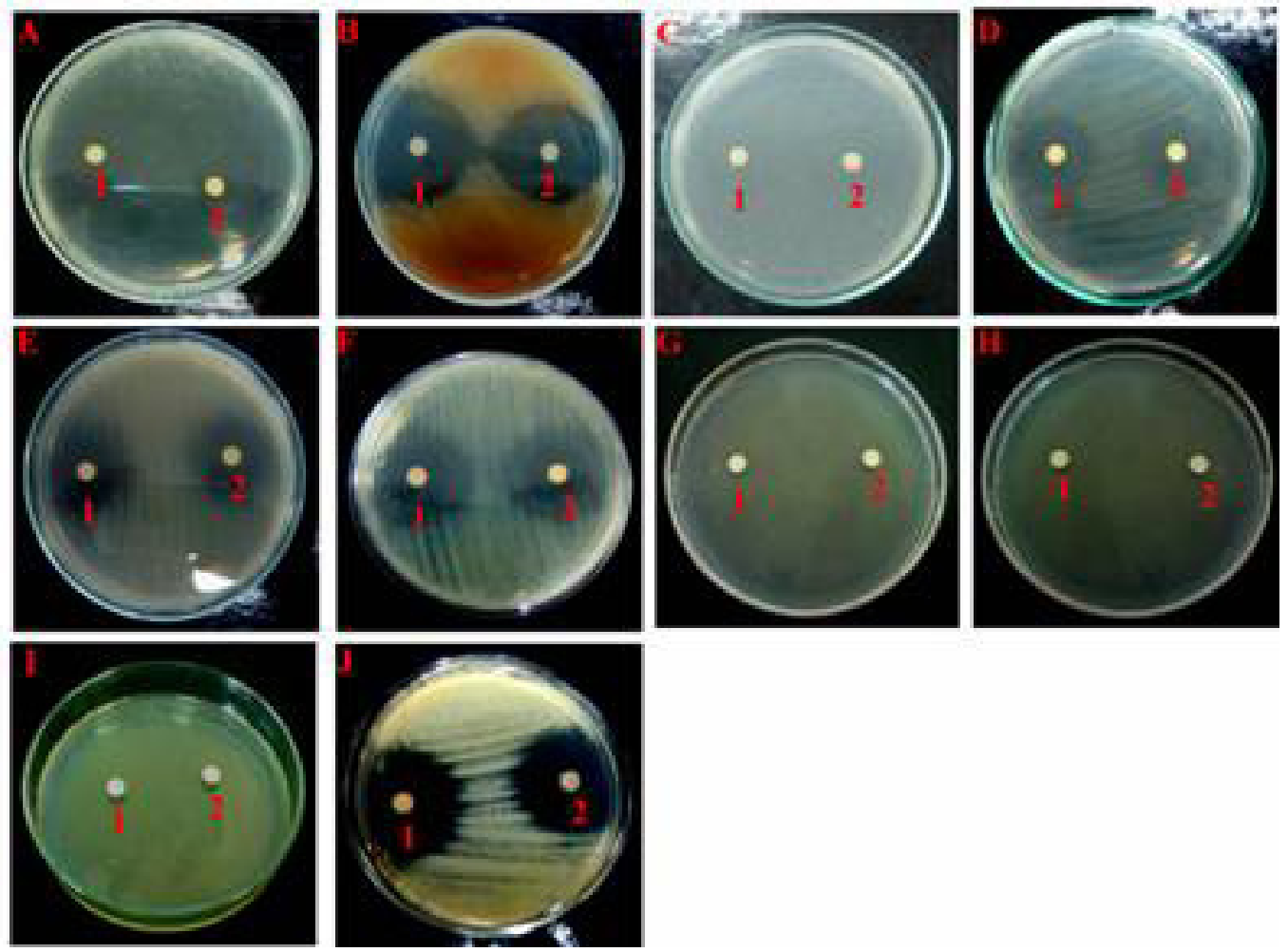

Font: Authors

For both EOs, it also noted that increasing oil

pathogens and also considerable antifungal concentrations resulted in higher inhibition zones (Tables 1 and 2). EOs antimicrobial activities are related to the composition of essential oil, the presence of phenols as major components, such as carvacrol and thymol that are the major components of $\mathrm{OEO}^{(5,12,13)}$ or eugenol that is the major component of $\mathrm{CEO}^{(5,12-13)}$ results in higher antimicrobial activities. Aktar et al. ${ }^{(4)}$ reported that clove and oregano essential oils have strong inhibitory effect against several bacterial activity against the wide range of fungal pathogens. They also reported that EOs affect the cell membrane of the pathogenic microorganism by causing an increase in permeability and leakage of vital intracellular constituents, resulting in the disruption of the cell respiration system and microbial enzyme system. Therefore, they have cytotoxic effects on living cells and these effects depend on to their type and concentration. 
Table 2 - Mean inhibition zone diameters $(\mathrm{mm})$ for the different volumes $(1,2,5$ and $10 \mu \mathrm{L})$ of clove essential oil in natura (IN) and thermally processed (TP) against the tested microorganisms.

\begin{tabular}{|c|c|c|c|c|c|c|c|c|}
\hline \multirow{4}{*}{ Microorganisms } & \multicolumn{5}{|c|}{ IN } & \multicolumn{2}{|c|}{$\mathrm{TP}$} & \\
\hline & \multicolumn{8}{|c|}{ Volume $(\mu \mathrm{L})$} \\
\hline & 1 & 2 & 5 & 10 & 1 & 2 & 5 & 10 \\
\hline & \multicolumn{8}{|c|}{ Inhibition zone (mm) } \\
\hline S. aureus & 20 & 25 & 28 & 30 & 20 & 25 & 28 & 30 \\
\hline MRSA & 15 & 16 & 16 & 19 & 15 & 16 & 16 & 19 \\
\hline B. cereus & 10 & 12 & 17 & 17 & 10 & 12 & 17 & 17 \\
\hline S. mutans & 8 & 10 & 12 & 13 & 8 & 10 & 12 & 13 \\
\hline E. faecalis & 9 & 10 & 12 & 13 & 9 & 10 & 12 & 13 \\
\hline E. coli & 10 & 12 & 14 & 15 & 10 & 12 & 14 & 15 \\
\hline S. Typhimurium & 10 & 12 & 13 & 13 & 10 & 12 & 13 & 13 \\
\hline C. albicans & 30 & 35 & TI & $\mathrm{TI}$ & 30 & 35 & $\mathrm{TI}$ & TI \\
\hline A. niger & 30 & 40 & 41 & 50 & 30 & 40 & 41 & 50 \\
\hline P. citrinum & 30 & 42 & 50 & 55 & 30 & 42 & 50 & 55 \\
\hline
\end{tabular}

Font: Authors

$\mathrm{TI}=$ total inhibition.

In general, $\mathrm{OEO}$ resulted in higher inhibition zones for all tested microorganisms (Tables 1 and 2). Ribeiro-Santos et al. ${ }^{(13)}$ compared the antimicrobial activity of oregano, cinnamon and sweet fennel essential oils, and observed that oregano essential oil exhibited the highest antimicrobial effect.

The results of minimal inhibitory concentrations (MIC) (Table 3) presented similar trends observed for the disk diffusion method results, MIC results were not affected by the thermal processing of both EOs, confirming that these oils can be thermally processed $\left(120^{\circ} \mathrm{C} / 5\right.$ min) maintaining their antimicrobial activity.

In general, MIC values observed for OEO were lower than values observed for CEO for all tested microorganisms, except for $S$. faecalis, for which both OEO and CEO presented the same MIC value $(10 \mu \mathrm{g} / \mathrm{mL})$. This confirms the higher effectiveness of OEO as an antimicrobial agent considering the microorganisms tested in this study. 
Figure 2 - Disk diffusion images using $5 \mu \mathrm{L}$ of in natura - CEO (1) and thermal processed CEO (2): (A) S. aureus; (B) B. cereus; (C) S. mutans; (D) E. faecalis; (E) E. coli; (F) S. Typhimurium; (G) C. albicans; (H) A. niger; (I) P. citrinum; (J) MRSA.
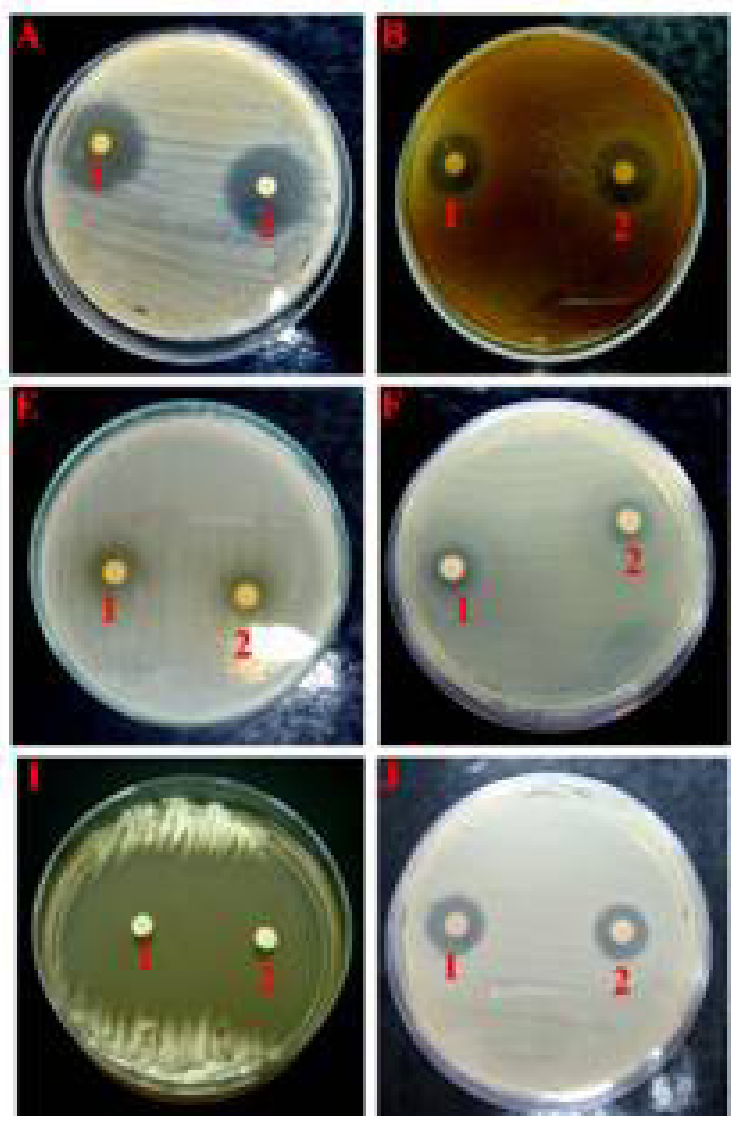

Font: Authors

S. aureus, B. cereus, S. mutans, C. albicans, A. niger, P. citrinum and MRSA were completely inhibited when it was employed $0.63 \mu \mathrm{g} / \mathrm{mL}$ of OEO, however for $E$. coli and $S$. Typhimurium it was necessary $1.25 \mu \mathrm{g} / \mathrm{mL}$ (Table 3 ). The highest MIC value observed for OEO was $10.00 \mu \mathrm{g} /$ $\mathrm{mL}$ for E. faecalis. CEO presented MIC values ranging from $1.25 \mu \mathrm{g} / \mathrm{mL}$ to $10 \mu \mathrm{g} / \mathrm{mL}$. Burt ${ }^{(5)}$ reported MIC values between 0.5 to $1.2 \mu \mathrm{g} / \mathrm{mL}$ for $S$. aureus, E.coli and $S$. Typhimurium for OEO, these values were very close to the values obtained in this study. For CEO, these authors reported MIC values ranging for 0.4 to $2.5 \mu \mathrm{g}$ / $\mathrm{mL}$ for the same microorganisms, however the values obtained in this study were higher, these variations can be attributed to the characteristics of the tested oil.
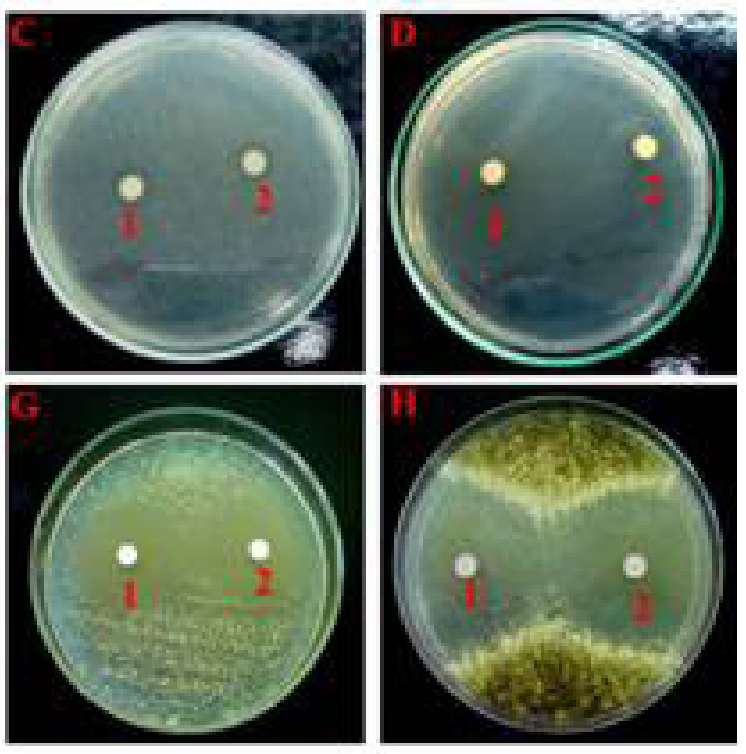

In general, for both OEO and CEO, MIC values were lower for Gram-positive bacteria and fungi than for Gram-negative bacteria (Table 3). Many essential oils have been reported as active against pathogenic fungi. Omidbeygi et al.(14) reported antifungal activity of essential oils of thyme, summer savory and clove on tomato paste against Aspergillus flavus. Kocic-Tanackov et al. ${ }^{(15)}$ showed that the increased of OEO concentration leads reduction in spore germination of Aspergillus spp. Serra et al. ${ }^{(16)}$ observed that several commercial essential oils presented antifungal activity against C. albicans and they related the mechanism of antifungal activity to the changing of cell wall morphology and permeability, denaturation of enzymes involved in cell wall synthesis and oxygen reactive species generation. 
Table 3 - Minimal inhibitory concentrations (MIC) of OEO and CEO in natura (IN) and thermally processed (TP).

\begin{tabular}{|c|c|c|c|c|}
\hline \multirow{3}{*}{ Microorganisms } & \multicolumn{4}{|c|}{$\mathrm{MIC}(\mu \mathrm{g} / \mathrm{mL})$} \\
\hline & \multicolumn{2}{|c|}{$\mathrm{OEO}$} & \multicolumn{2}{|c|}{$\mathrm{CEO}$} \\
\hline & IN & TP & IN & $\mathrm{TP}$ \\
\hline S. aureus & 0.63 & 0.63 & 5.00 & 5.00 \\
\hline MRSA & 0.63 & 0.63 & 10.00 & 10.00 \\
\hline B. cereus & 0.63 & 0.63 & 5.00 & 5.00 \\
\hline S. mutans & 0.63 & 0.63 & 5.00 & 5.00 \\
\hline E. faecalis & 10.00 & 10.00 & 10.00 & 10.00 \\
\hline E. coli & 1.25 & 1.25 & 10.00 & 10.00 \\
\hline$S$. Typhimurium & 1.25 & 1.25 & 10.00 & 10.00 \\
\hline C. albicans & 0.63 & 0.63 & 1.25 & 1.25 \\
\hline A. niger & 0.63 & 0.63 & 1.25 & 1.25 \\
\hline P. citrinum & 0.63 & 0.63 & 1.25 & 1.25 \\
\hline
\end{tabular}

Font: Authors

The antimicrobial activities of the essential oils were higher on Gram-positive bacteria than Gram-negative bacteria and our results are according to other authors. ${ }^{(3,13,17-19)}$ Possibly, this could be related to the absence of an outer membrane around the cell wall in Gram-positive bacteria. An external membrane is only present in Gram-negative bacteria and may restrict the diffusion of hydrophobic compounds through the lipopolysaccharide covering. Ribeiro-Santos et al. ${ }^{(13)}$ stressed that the lower antimicrobial activity against the Gram-negative strains may be due to a higher resistance of these microorganisms provided by the external lipopolysaccharide wall surrounding the peptidoglycan cell wall.

\section{Conclusion}

In this work, were analyzed antimicrobial activity of oregano and clove essential oils over a range of bacteria, molds and yeast of importance as pathogens or food spoilage. Both OEO and $\mathrm{CEO}$ presented the same inhibition zones for in natura and after thermal processing $\left(120^{\circ} \mathrm{C} / 5\right.$ $\mathrm{min}$ ), for all tested microorganisms, indicating that these oils can be thermally processed maintaining their antimicrobial activity. For OEO and CEO, the more sensitive microorganisms were the fungi (Aspergillus niger, Penicillium citrinum and Candida albicans), followed by Staphylococcus aureus, Bacillus cereus and Methicillin - resistant Staphylococcus aureus (MRSA); the lowest antimicrobial activities were observed against Streptococcus mutans and Enterococcus faecalis. In general, OEO resulted in higher inhibition zones and lower MIC values for all tested microorganisms, suggesting that it was more effective as an antimicrobial agent than CEO. Therefore, OEO and CEO can be used as promising alternatives to be used as natural antimicrobial substances in food industry.

\section{Acknowledgments}

The authors wish to thank the CAPES - Brazil for granting a masters scholarship to Flávia Debiagi. 


\section{References}

1 Nascimento CR, Silva EM, São-José JFB. Good hygiene practices and microbiological contamination in commercial restaurants. Afr J Microbiol Res. 2018 Apr;12(16):362-9. doi: 10.5897/AJMR2018.8831.

2 Health Surveillance Secretariat. Outbreaks of transmitted diseases by food in Brazil [Internet]. Available at: http://portal.saude. gov.br/. Accessed November 2018. http:// portalarquivos2.saude.gov.br/images/ pdf/2018/julho/02/Apresentacao-Surtos-DTAJunho-2018.pdf

3 Falcó I, Verdeguer M, Aznar R, Sánchez G, Randazzo W. Sanitizing food contact surfaces by the use of essential oils. Innov Food Sci Emerg Technol. 2019 Jan; 51:220-228. doi: 10.1016/j.ifset.2018.02.013.

4 Aktar MS, Degaga B, Azam T. Antimicrobial activity of essential oils extracted from medicinal plants against the pathogenic microorganisms: a review. Issues Biol Sci Pharm Res. 2013 Jan;2(1):1-7.

5 Burt S.Essential oils: their antibacterial properties and potential applications in foods-a review. Int J Food Microbiol. 2004 Ago;94(3):223-53. doi: 10.1016/j.ijfoodmicro.2004.03.022.

6 Khayyat SA, Roselin LS. Recent progress in photochemical reaction on main components of some essential oils. J Saudi Chem Soc. 2018 Nov;22(7):855-75. doi: 10.1016/j. jscs.2018.01.008.

7 Dutra TV, Castro JC, Menezes JL, Ramos TR, do Prado IN, Machinski M, et al. Bioactivity of oregano (Origanum vulgare) essential oil against Alicyclobacillus spp. Ind Crops Prod. 2019 Mar;129:345-9. doi: 10.1016/j. indcrop.2018.12.025.

8 Gómez-Estaca J, López de Lacey A, LópezCaballero ME, Gómez-Guillén MC, Montero P. Biodegradable gelatin-chitosan films incorporated with essential oils as antimicrobial agents for fish preservation. Food Microbiol. 2010 Oct;27(7):889-896. doi: 10.1016/j. fm.2010.05.012.
9 Dong L, Tong Z, Linghu D, Lin Y, Tao R, Liu J, Tian Y, Ni L. Effects of sub-minimum inhibitory concentrations of antimicrobial agents on Streptococcus mutans biofilm formation. Int J Antimicrob Ag 2012 May;39(5):390-5. doi: 10.1016/j.ijantimicag.2012.01.009.

10 Michelin DC, Moreschi PE, Lima AC, Nascimento GGF, Paganelli MO, Chaud MV. Avaliação da atividade antimicrobiana de extratos vegetais. Rev Bras Farmacogn. 2005 Oct-Dec;15(4):316-20. doi: 10.1590/S0102695X2005000400010.

11 Yoshida, A., Kuramitsu, H. K. Multiple Streptococcus mutans genes are involved in biofilm formation. Appl. Environ. Microb. 2012 Dec;68:6284-91. doi: 10.1128/ AEM.68.12.6283-6291.2002.

12 Chouhan S, Sharma K, Guleria S. Antimicrobial activity of some essential oils-present status and future perspectives. Medicines. 2017 Sep;4(3):1-21. doi:10.3390/ medicines4030058.

13 Ribeiro-Santos R, Ventura LAF, Santos DC, Melo NR, Costa BS. Effects of oregano, cinnamon, and sweet fennel essential oils and their blends on foodborne microorganisms. IFRJ. 2018 Apr;25(2):540-4.

14 Omidbeygi M, Barzegar M, Hamidi Z, Naghdibadi H. Antifungal activity of thyme, summer savory and clove essential oils against Aspergillus flavus in liquid medium and tomato paste. Food Control. 2007 Dec;18(12):151823. doi: 10.1016/j.foodcont.2006.12.003.

15 Kocic-Tanackov S, Dimic G, Tanackov I, Pejin D, Mojovic L, Pejin J. The inhibitory effect of oregano extract on the growth of Aspergillus spp. and on sterigmatocystin biosynthesis. LWT - Food Sci Technol. 2012 Nov;49(1):1420. doi: :10.1016/j.lwt.2012.04.013.

16 Serra E, Hidalgo-Bastida L, Verran J, Williams D, Malic S. Antifungal activity of commercial essential oils and biocides against Candida Albicans. Pathogens. 2018 Jan;7(1):1-15. doi:10.3390/pathogens7010015. 
17 Alvarez MV, Ortega-Ramirez LA, SilvaEspinoza BA, Gonzalez-Aguilar GA, AyalaZavala JF. Antimicrobial, antioxidant, and sensorial impacts of oregano and rosemary essential oils over broccoli florets. J Food Process Preserv. 2019 Mar;43(3):e13889. doi: doi.org/10.1111/jfpp.13889.

18 Khalil N, Ashour M, Fikry S, Singab AN, Salama O. Chemical composition and antimicrobial activity of the essential oils of selected apiaceous fruits. Future J Pharm Sci. 2018 Jun;4(1):88-92. doi: 10.1016/j. fjps.2017.10.004.

19 Ryu V, McClements DJ, Corradini MG, McLandsborough L. Effect of ripening inhibitor type on formation, stability, and antimicrobial activity of thyme oil nanoemulsion. Food Chem. 2018 Apr;245:104-11. doi: 10.1016/j. foodchem.2017.10.084. 